\title{
PENGEMBANGAN TES KEMAMPUAN PENALARAN MATEMATIS PESERTA DIDIK MADRASAH TSANAWIYAH DI MAKASSAR
}

\author{
Nursalam ${ }^{1}$, Andi Dian Angriani ${ }^{2}$, Husnaeni Usman ${ }^{3}$ \\ 1,2,3Fakultas Tarbiyah dan Keguruan UIN Alauddin Makassar \\ 1,2,3Kampus II: Jalan H. M Yasin Limpo No. 36 Samata-Gowa \\ E-mail: nursalam_ftk@uin-alauddin.ac.id ${ }^{1}$, dian.angriani@uin-alauddin.ac.id², \\ usmanhusnaeni10@gmail.com ${ }^{3}$
}

\begin{abstract}
Abstrak:
Penelitian ini bertujuan untuk mengetahui prosedur pengembangan dan kualitas instrumen tes untuk mengukur kemampuan penalaran matematis peserta didik Madrasah Tsanawiyah Kota Makassar. Jenis penelitian yang digunakan adalah penelitian research and development (R\&D) yaitu pengembangan instrumen tes yang terdiri atas: kisi-kisi tes, soal tes, kunci jawaban soal, dan pedoman penilaian. Model pengembangan perangkat ini dikembangkan berdasarkan model pengembangan tipe formative research Tessmer, yaitu: (1) tahap preliminary, (2) tahap self evaluation, (3) tahap prototyping, dan (4) tahap field test. Subjek uji coba dalam penelitian ini adalah peserta didik kelas 8 MTsN 1 Model Kota Makassar. Berdasarkan hasil uji coba terbatas yang dilakukan, diperoleh bahwa: (1) perangkat pembelajaran sudah dikatakan "valid" karena memiliki nilai CVI sebesar 1 dan reliabilitas tergolong reliabel dengan nilai sebesar 0.742 . Hasil rata-rata tingkat kesukaran yaitu 0,362 dengan kategori "sedang". Hasil rata-rata daya pembeda yaitu 0,367 dengan kategori "baik", serta hasil rata-rata kemampuan penalaran matematis peserta didik yaitu 36,18 dengan kategori kurang sehingga guru agar melatihkan soal-soal kepada peserta didik untuk meningkkatkan kemampuan penalaran matematis.
\end{abstract}

\begin{abstract}
:
This thesis discusses the development of test instruments to measure students' mathematical reasoning abilities of students of MTsN 1 Model of Makassar City valid, practical and effective. The type of research used is research and development (R \& D) research, namely the development of test instruments consisting of: test grille, test questions, answer key questions, and assessment guidelines. This development model was developed based on Tessmer formative research type development model, namely: (1) preliminary stage, (2) self evaluation stage, (3) prototyping stage, and (4) field test stage. The subjects of the experiment in this study were the students of class 8 MTsN 1 Model Makassar City. Based on the results of the limited trial conducted, it is found that: (1) learning devices are said to be "valid" because it has a CVI value of 1 and reliabilities classified reliabel with a value of 0.742 . The average yield of the level of difficulty is 0.362 with the category "medium". The average yield of the differentiating power is 0.367 with the category of "good". As well as the average result of students' mathematical reasoning ability is 36.18 with less category so it is still very needed further effort by the teacher in order to provide the problems that can spur the ability of mathematical reasoning.
\end{abstract}

Kata kunci:

Penelitian Pengembangan, Instrumen Tes, Penalaran Matematis 
BELAJAR merupakan proses seseorang dalam mengubah dirinya untuk menjadi lebih baik yang berlandaskan dari pengalaman. Proses belajar terjadi melalui banyak cara, ada yang disengaja, ada pula yang tidak disengaja dan itu berlangsung sepanjang waktu agar seseorang mampu berubah. Perubahan yang dimaksud adalah dalam hal pengetahuan, pemahaman, keterampilan dan kebiasaan yang baru. Proses belajar juga terdiri dari tiga tahapan yang dikemukakan oleh Bruner yaitu tahap informasi, transformasi, dan evaluasi. Proses informasi adalah proses penjelasan, penguraian tentang prinsip-prinsip struktur pengetahuan, keterampilan dan sikap. Tahap transformasi adalah tahap yang dilakukan setelah tahap informasi, pada tahap ini peran pengajar sangat diperlukan karena informasi tersebut harus diubah atau ditransformasikan ke bentuk yang lebih abstrak dan konseptual sehingga dapat digunakan dalam konteks yang lebih luas. Tahap evaluasi untuk mengetahui sejauh mana kemampuan seseorang dalam memahami dan menerima informasi tersebut. Belajar dapat diartikan sebagai perubahan perilaku seseorang dari belum tahu menjadi tahu, belum paham menjadi paham, dari kebiasaan lama menjadi kebiasaan baru, dari belum terampil menjadi terampil, serta bermanfaat bagi lingkungan dan dirinya sendiri. (Wassid \& Sunendar, 2008: 4; Al-Tabany, 2015: 18). Oleh karena itu, dengan proses belajar maka seseorang diharapkan dapat menunjukkan perubahan positif yang terjadi pada dirinya.

Salah satu ciri kegiatan belajar adalah terjadi interaksi antara satu orang dengan orang lain yang dalam pendidikan formal dikenal dengan istilah proses pembelajaran. Pembelajaran merupakan suatu aktivitas transfer informasi yang melibatkan dua pihak yaitu pendidik sebagai pemberi informasi dan peserta didik sebagai penerima informasi. Pembelajaran dapat pula diartikan sebagai usaha dalam menciptakan lingkungan yang mengoptimalkan proses belajar, menjadikan lingkungan, guru, perpustakaan, laboratorium, alat peraga, serta semua yang berkaitan dengan kegiatan belajar mengajar sebagai sumber belajar. Pembelajaran menuntut keaktifan peserta didik dan pendidik. Jadi, jika hanya pendidik yang aktif dalam proses tersebut maka itu hanya dinamakan sebagai mengajar, juga sebaliknya jika hanya peserta didik yang aktif dalam proses pembelajaran tersebut maka itu hanya dinamakan belajar (Amri, 2013: 28). Dengan demikian proses pembelajaran membutuhkan interaksi dan partisipasi aktif antara pendidik dan peserta didik. Pendidik harus menciptakan suasana yang bisa membuat peserta didik untuk terlibat dalam setiap aktivitas agar mampu memahami, menguasai, berpikir kritis, dan melakukan penalaran terhadap materi yang disajikan.

Salah satu tujuan proses pembelajaran adalah tercapainya tujuan pembelajaran. Dalam merancang pembelajaran, terdapat banyak tujuan yang ingin dicapai baik dari aspek sikap, pengetahuan, maupun keteramplan. Oleh karena itu, seorang pendidik perlu merancang suatu alat ukur untuk mengetahui ketercapaian tujuan dari masingmasing aspek yang telah ditentukan termasuk dalam pelaksanaan pembelajaran matematika yang merupakan salah satu mata pelajaran wajib disetiap jenjang dan satuan pendidikan. 
Matematika merupakan salah satu pelajaran yang mampu meningkatkan cara berpikir kritis dan logis peserta didik, karena pada dasarnya matematika terbentuk dari hasil pemikiran manusia yang membutuhkan analisis, cara berpikir kritis, dan penalaran. Selain itu, pengalaman manusia menjadi salah satu hal yang mendasari terbentuknya matematika. Hal ini sejalan dengan yang dikemukakan oleh Kusumayanti \& Wutsqa, (2016: 2) bahwa pengalaman manusia dapat dianalisis dengan penalaran dalam struktur kognitif hingga terbentuk konsep-konsep matematika, kemudian diolah menjadi bahasa matematika agar mudah dipahami dan mudah dimanipulasi secara benar.

Salah satu kemampuan dasar yang perlu dikuasai oleh peserta didik adalah kemampuan penalaran matematis. Pendidik dalam proses pembelajaran perlu melatihkan peserta didik dengan soal latihan yang mengarahkan pada kemampuan penalaran agar para peserta didik terbiasa dalam bernalar untuk menyelesaikan suatu permasalahan. Fakta menunjukkan bahwa peserta didik lemah dalam menyelesaikan masalah matematika yang berkaitan dengan kemampuan penalaran, khususnsya penalaran logis matematik (English, 2004: 10). Selain itu, hasil dari Programme for International Student Assessment (PISA) tahun 2015 yang menempatkan Indonesia diurutan 69 dari 76 negara dan laporan Trends International Mathematics and Science Study (TIMSS) tahun 2015 yang mengukur kemampuan anak usia 15 tahun dalam literasi membaca, matematika, dan ilmu pengetahuan alam untuk tingkat SMP kelas 8, peserta didik Indonesia hanya berada pada rangking 36 dari 49 negara dalam hal melakukan prosedur ilmiah dengan rata-rata skor matematika 386, ilmu pengetahuan 403 dan membaca 397.

Salah satu komponen soal yang diujikan dalam TIMSS adalah domain kognitif pada level penalaran. Pada level inilah peserta didik banyak mengalami kesalahan dalam menyelesaikan tes. Oleh sebab itu, informasi yang diperoleh dari PISA maupun TIMMS ini dapat dijadikan acuan bagi para pendidik dalam menyusun soal-soal latihan atau tes disetiap satuan pendidikan. Namun, fakta menunjukkan bahwa guruguru masih lemah dalam menyusun dan mengembangkan instrumen tes untuk mengukur kemampuan penalaran peserta didik, khususnya kemampuan penalaran matematis, sehingga perlu dikembangkan soal-soal yang lebih mengarah pada melatih anak dalam hal berpikir matematis. Beberapa penelitian pernah dilakukan terkait dengan pengembangan instrumen tes untuk mengukur kemampuan penalaran matematis diantaranya Hapizah (2014); Manfaat, Nurhairiyah, \& Cirebon, n.d. (2014); Jurnaidi \& Zulkardi (2013); Bieda, Ji, Drwencke, \& Picard (2013); dan Johnson (2012). Hal ini dilakukan karena melihat pentingnya mengembangkan kemampuan penalaran matematis peserta didik dalam menyelesaikan masalah-masalah kontekstual.

Mengingat pentingnya instrumen tes yang melatih peserta didik dalam meningkatkan kemampuan penalaran matematis, maka artikel ini memaparkan hasil pengembangan instrumen tes untuk mengukur kemampuan penalaran matematis dan kualitas tes kemampuan penalaran matematis ditinjau dari tingkat kesukaran dan index daya pembeda setiap butir yang dikembangkan. 


\section{PENALARAN MATEMATIS}

Penalaran merupakan suatu proses berpikir untuk menarik kesimpulan yang tepat berdasarkan kejadian-kejadian yang ada dan menurut aturan tertentu. Ciri-ciri dari penalaran yaitu pola berpikir logis dan proses berpikir analitik. (Sa'adah, 2010: 14). Penalaran matematika juga biasa dikenal dengan mathematical reasoning. Terkait dengan penalaran matematika, Brodie (2010: 7) mengemukakan bahwa penalaran matematis merupakan penalaran tentang objek matematika seperti statistika, aljabar, geometri dan sebagainya merupakan bagian dari objek matematika .

Gardner, et al., (2006) mengungkapkan bahwa penalaran matematis adalah kemampuan menganalisis, menggeneralisasi, mensistesis/mengintegrasikan, memberikan alasan yang tepat dan menyelesaikan masalah tidak rutin. (Lestari, 2015: 82). Sedangkan menurut Susiana Nurhayati \& Rosyidi (2013: 2), penalaran matematika adalah suatu kegiatan menyimpulkan fakta, menganalisa data, memperkirakan, menjelaskan dan membuat suatu kesimpulan.

Dari beberapa penjelasan terkait penalaran matematis, dapat disimpulkan bahwa penalaran matematika merupakan suatu proses penyimpulan fakta, analisa, dan prediksi dalam membuat suatu kesimpulan.

\section{KUALITAS TES}

Instrumen adalah alat ukur dalam rangka pengumpulan data. Dalam ilmu sosial sains banyak ahli yang telah membakukan alat ukur atau instrumen untuk beberapa kebutuhan pengukuran. Dalam penelitian sosial bila hendak menggunakan alat ukur baku untuk pengukuran maka pengumpulan data perlu melaporkan hasil pengujian kualitas ukur oleh orang yang telah membakukannya. (Purwanto, 2010: 6).

Instrumen tes yang merupakan bagian dari tes dipilah menjadi empat bagian, yakni kuesioner, tes, inventori, dan pedoman observasi. Tes merupakan alat yang digunakan untuk mengukur kemampuan seseorang dalam bidang tertentu yaitu berupa instrumen yang telah dirancang sebelumnya dan kemampuan bahasa inventori dapat dikategorikan sebagai instrumen yang dipakai untuk karakteristik (psikologis) tertentu dari individu. Instrumen yang berupa skala sikap adalah salah satu contoh instrumen yang tergolong dalam kategori inventori. Sedangkan istilah kuesioner dikenakan pada instrumen yang digunakan dalam menjaring data yang sifatnya informatif faktual (fakta konkrit). Misalnya data tentang umur, tingkat pendidikan, jenis penataran yang pernah diikuti dan sejenisnya. (Mustami, 2015: 103).

Menurut Arikunto (2010: 57), sebuah tes dikatakan baik jika memenuhi validitas, reliabilitas, objektivitas, praktikabilitas, serta ekonomis. Tes dikatakan juga sebagai alat pengukur kemampuan individu dalam suatu pelajaran tertentu dan memiliki standar objektif, sebagai prosedur yang sistematis untuk mengetahui karakteristik seseorang dengan menggunakan sistem kategori. Orang masih memandang bahwa keberhasilan seseorang dalam proses pendidikan adalah dilihat dari seberapa banyak seseorang menguasai materi yang telah diajarkan. Oleh sebab itu, tes masih banyak digunakan dalam dunia pendidikan. (Hamzah, 2014: 100) 
Istilah tes lazim diartikan sebagai "penyajian seperangkat pertanyaan atau soal untuk dijawab oleh peserta tes". Istilah tes dipandang sebagai istilah yang mengandung pengertian yang paling sempit yakni bermakna sebagai salah satu alat pengukuran tingkat kemampuan peserta tes (Ishak dan Syamsudduha, 2011: 3).

Pandangan yang diuraikan di atas didasarkan pada kenyataan bahwa dari jawaban peserta tes terhadap soal-soal yang disajikan kepada mereka, diperoleh suatu ukuran tertentu tentang tingkat kemampuan kognitif, psikomotorik dan afektifnya. Kemampuan-kemampuan tersebut menunjukkan karakteristik khas peserta tes yang berkaitan dengan hasil belajarnya. Dengan demikian dapat dibuat suatu rumusan bahwa tes adalah salah satu alat pengukur hasil belajar peserta didik.

\section{METODE PENELITIAN}

Jenis penelitian yang digunakan dalam penelitian ini adalah penelitian pengembangan (Research and Development). Model pengembangan yang digunakan adalah model pengembangan tipe formative research Tessmer (1993). Subjek penelitian ini adalah peserta didik kelas 8 Madrasah Tsanawiyah Kota Makassar. Teknik analisis data yang digunakan pada instrumen tes kemampuan penalaran matematis adalah analisis validitas isi soal, analisis angket respon peserta didik, uji reliabilitas, uji tingkat kesukaran, daya pembeda, dan analisis data hasil kemampuan penalaran matematis. Berikut disajikan alur pengembangan tes model Tessmer.

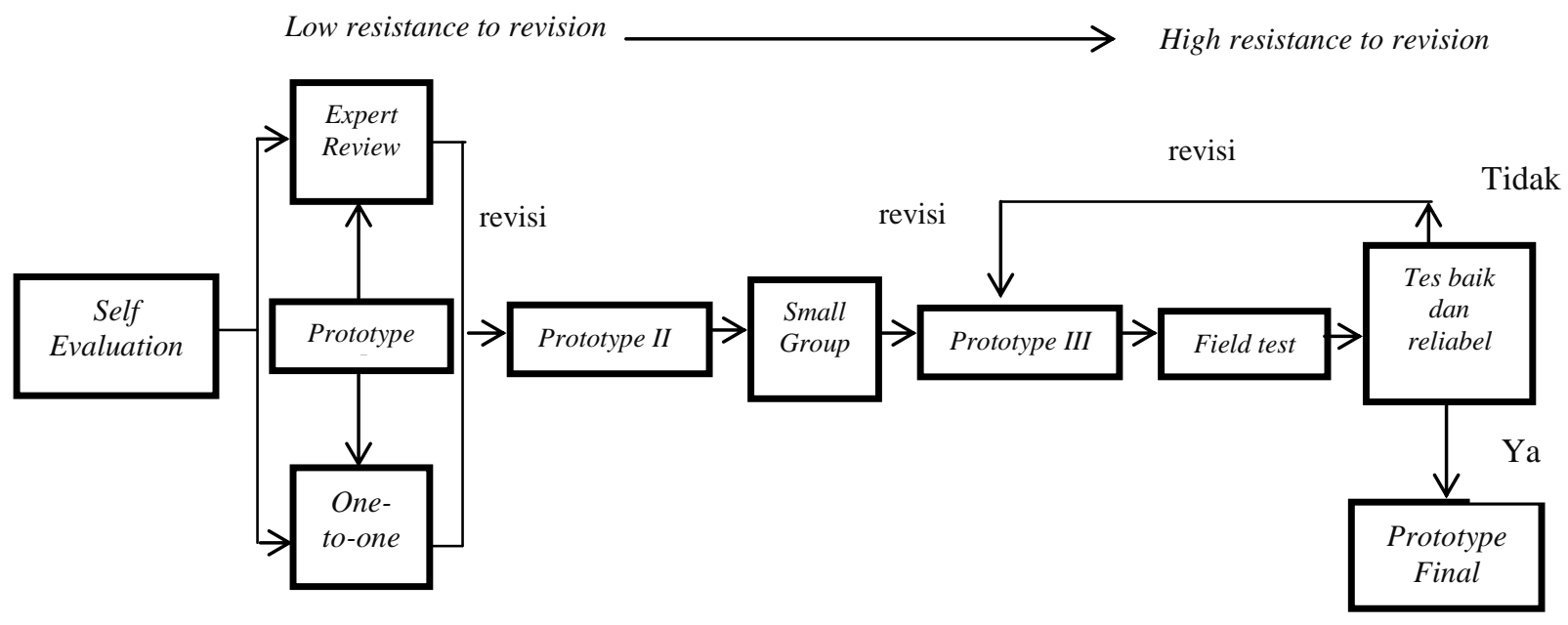

Gambar 1: Diagram Alur Pengembangan Instrumen Tes Model Tessmer

\section{HASIL PENELITIAN}

\section{Pengembangan Instrumen Tes Kemampuan Penalaran Matematis}

Prosedur pengembangan instrumen tes untuk mengukur kemampuan penalaran matematis peserta didik Madrasah Tsanawiyah di Kota Makassar pada penelitian ini mengikuti tahapan-tahapan pada prosedur pengembangan yang telah dicantumkan pada bagian metode penelitian. Proses pengembangan dapat diuraikan sebagai berikut. 


\section{Tahap Preliminary}

Tahapan ini diawali dengan pengumpulan beberapa referensi yang berkaitan dengan penelitian pengembangan, instrumen tes dan kemampuan penalaran matematis peserta didik. Berdasarkan kajian tersebut, maka dipilih suatu teori yang dikemukakan oleh Sumarno, yang menjelaskan bahwa indikator penalaran yaitu; (1) menarik kesimpulan logis; (2) memberikan penjelasan dengan model, sifat-sifat, dan hubungan; (3) memperkirakan jawaban dan proses solusi; (4) menggunakan pola dan hubungan untuk menganalisis situasi atau membuat analogi dan generalisasi; (5) menyusun dan menguji konjektur; (6) membuat counter example; (7) mengikuti aturan inferensi dan memeriksa validitas argumen; (8) menyusun argumen yang valid; (9) menyusun pembuktian langsung, tidak langsung, dan menggunakan induksi matematika.

Pada tahapan ini juga dilakukan kegiatan pemilihan tempat dan subjek uji coba, dan tempat uji coba yang dipilih adalah MTsN 1 Makassar. Kegiatan selanjutnya adalah melakukan kegiatan observasi untuk mengidentifikasi kegiatan pembelajaran dan kemampuan penalaran matematis peserta didik di MTsN 1 Makassar.

\section{Tahap Self Evaluation}

Tahapan ini bertujuan untuk merancang sebuah instrumen tes untuk mengukur kemampuan penalaran matematis yang berdasarkan pada hasil tahap preliminary. Instrumen tes yang akan dirancang terdiri dari kisi-kisi tes, soal tes, lembar jawaban tes, dan tabel penskoran. Tahapan ini ada 4 kegiatan, yaitu analisis kurikulum, analisis materi, analisis peserta didik, dan desain.

1. Analisis kurikulum

Tahapan ini dilakkukan untuk menetapkan masalah yang diperlukan dalam pengembangan tes, dalam hal ini tes kemampuan penalaran matematis peserta didik. Kurikulun yang dianalisis adalah kurikulum matematika Madrasah Tsanawiyah. Analisis kurikulum yang dilakukan berorientasi pada pencapaian kompetensi yang mencakup aspek kognitif, sikap, dan keterampilan.

Pada tahap ini juga, dilakukan analisis pada proses pembelajaran yang menerapkan pendekatan saintifik (saintific approach). Kegiatan ini dilakukan dengan tujuan agar peserta didik mampu meningkatkan kemampuan penalaran matematis peserta didik dalam kegiatan pembelajaran.

\section{Analisis Peserta didik}

Kegiatan analisis peserta didik difokuskan pada peserta didik kelas 8 sebagai subjek uji coba karena materi telah dipelajari di kelas 8 . Rata-rata jumlah peserta didik pada masing-masing kelas tersebut adalah 40 peserta didik. Berdasarkan observasi dan hasil wawancara dari guru matematika, dapat diketahui bahwa pengetahuan matematika peserta didik kelas 8 bervariasi, ada yang berkemampuan kurang, sedang dan tinggi. Hal ini menunjukkan adanya faktor dari minat yang dimiliki oleh setiap peserta didik berbeda-beda terhadap pelajaran matematika. Secara umum kemampuan penalaran matematis peserta didik belum pernah ditelusuri baik oleh guru maupun peneliti lain. 


\section{Analisis Materi}

Analisis materi merupakan kegiatan mengidentifikasi konsep-konsep utama yang akan digunakan dalam tes pada materi kelas 8. Berdasarkan kegiatan analisis kurikulum, didapatkan bahwa materi yang akan digunakan dalam pengembangan instrumen tes sesuai dengan materi pada Kurikulum 2013 untuk mata pelajaran matematika kelas 8 semester genap. Materi tersebut adalah lingkaran, bangun ruang sisi datar, sistem persamaan linear dua variabel, dan peluang.

Selanjutnya dari materi tersebut dipilih beberapa subpokok bahasan dari tiap materi. Berdasarkan hal itu dapat dikembangkan indikator untuk setiap soal yaitu:

a. Menyajikan pernyataan matematika secara lisan, tertulis, gambar dan grafik;

b. Melakukan manipulasi matematika;

c. Menyusun bukti, memberikan alasan atau bukti terhadap beberapa solusi;

d. Menarik kesimpulan dari pernyataan;

e. Memeriksa kesahihan argumen.

4. Desain

Setelah kegiatan analisis materi dilakukan tahapan selanjutnya adalah merancang atau mendesain instrumen tes kemampuan penalaran matematis yang meliputi: kisi-kisi tes, soal tes, lembar jawaban dan pedoman penilaian. Tahapan awal dilakukan peneliti adalah merancang soal tes kemampuan penalaran matematis. Soal-soal tes dirancang berdasarkan materi yang telah dianalisis dan berdasarkan indikator kemampuan penalaran matematis.

Peneliti merancang instrumen tes berupa tes uraian berdasarkan indikator penalaran matematis. Penampilan soal tes juga dirancang dengan baik agar peserta didik tertarik dalam mengerjakan soal, salah satu contohnnya adalah dengan memunculkan gambar yang bersifat kontekstual.

Kegiatan lainnya adalah membuat/menyusun kisi-kisi tes, dan lembar jawaban sebagai bahan pertimbangan bagi validator untuk memeriksa validitas dari instrumen tes tersebut. Kisi-kisi instrumen tes dirancang berdasarkan pada indikator penalaran pada setiap soal, lembar jawaban dirancang dengan memuat langkah-langkah penyelesaian setiap soal untuk melatih kemampuan penalaran matematis. Selain itu, peneliti juga merancang pedoman penskoran yang digunakan untuk mempermudah peneliti atau guru dalam memberikan penilaian terhadap hasil tes kemampuan penalaran matematis yang telah dikerjakan peserta didik.

Tahap Prototyping (Validasi, Evaluasi, dan Revisi)

Tujuan dari tahap prototyping ini adalah untuk menghasilkan prototype II dari instrumen tes yang telah direvisi berdasarkan masukan dari para ahli (expert review) dan data yang diperoleh dari uji coba one-to-one. Kegiatan pada tahap ini meliputi validasi instrumen oleh validator diikuti dengan revisi dan uji coba dengan tiga peserta didik yang sebaya tetapi nonsubjek. Hasil kegiatan tahap prototyping ini dijelaskan sebagai berikut: 


\section{Expert Review}

Expert Review (penilaian para ahli) digunakan sebagai dasar melakukan revisi dan penyempurnaan prototipe. Validasi instrumen dilakukan dengan cara memberikan lembar validasi instrumen kisi-kisi tes, soal tes, dan lembar jawaban kepada validator, yang terdiri atas dua dosen matematika Universitas Islam Negeri Alauddin Makassar dan satu guru matematika MTsN 1 Model Kota Makassar.

Dalam tahap ini, validator menilai 10 aspek yang berkaitan dengan instrumen yang telah dirancang (Prototype I). Validator memberikan pendapat bahwa instrument yang dibuat masih memiliki beberapa kekurangan sehingga perlu dilakukan revisi. Hasil komentar dan saran dari validator tersebut digunakan sebagai bahan pertimbangan untuk merevisi prototype instrumen tes sehingga dihasilkan prototype kedua.

2. One-to-one

Tahap selanjutnya yang dilakukan pada proses pengembangan ini adalah tahap one-to-one, dengan melibatkan beberapa peserta didik. Peserta didik yang dipilih merupakan peserta didik yang sebaya nonsubjek uji coba penelitian yang berkemampuan tinggi, sedang, dan rendah berdasarkan nilai hasil belajar yang diketahui oleh guru matematika yang mengajar ketiga peserta didik tersebut. Soal-soal tersebut diujicobakan pada peserta didik untuk dimintai komentar terhadap soal-soal tersebut tentang keterbacaan soal-soal tersebut.

\section{Small Group}

Selain soal instrumen tes kemampuan penalaran matematis divalidasi oleh ahli, dan diujicobakan pada one to one. Soal tersebut juga diuji cobakan small group pada beberapa peserta didik Madrasah Tsanawiyah di Makassar. Para peserta didik yang terlibat diminta untuk membaca soal-soal yang telah dibuat, untuk mengetahui ada tidaknya butir soal yang multi tafsir pada peserta didik.

\section{Tahap Field Test (Uji Coba Lapangan)}

Prototype yang telah divalidasi dan direvisi (prototype II), diujicobakan pada subjek uji coba penelitian, yaitu peserta didik kelas 8 MTsN 1 Makassar dengan jumlah responden 40 peserta didik. Hasil yang diperoleh dari pekerjaan peserta didik kelas 8 MTsN 1 Kota Makassar ini dianalisis untuk mengukur atau mengetahui tingkat kemampuan penalaran matematis peserta didik. Selain itu berdasarkan hasil kerja peserta didik tersebut dianalisis juga nilai reliabilitas, tingkat kesukaran, serta daya pembeda. Pada tahap ini, dilakukan juga revisi terhadap instrumen yang sudah diujikan tersebut agar menghasilkan sebuah produk yang sesuai.

\section{Kualitas Butir Tes Kemampuan Penalaran Matematis}

\section{Uji Validitas Isi Soal}

Uji validitas isi dilakukan untuk mengetahui kesesuaian item soal dengan materi yang akan diukur yang melibatkan para ahli. Para ahli yang terlibat dalam proses judgement validitas isi instrumen tes untuk mengukur kemampuan penlaran matematis antara lain: dua orang dosen program studi matematika dan satu orang guru matematika kelas VII. Hasil analisis validitas isi dapat dilihat pada Tabel 1 berikut: 
Tabel 1. Hasil Analisis CVI dan CVR

\begin{tabular}{|c|c|c|c|c|c|}
\hline Item & R1 & R2 & R3 & CVR & Keterangan \\
\hline 1 & 1 & 2 & 2 & 0,33 & Butir tidak mendukung validitas isi tes \\
\hline 2 & 2 & 1 & 2 & 0,33 & Butir tidak mendukung validitas isi tes \\
\hline 3 & 2 & 2 & 2 & 1 & Butir mendukung validitas isi tes \\
\hline 4 & 2 & 2 & 2 & 1 & Butir mendukung validitas isi tes \\
\hline 5 & 2 & 2 & 2 & 1 & Butir mendukung validitas isi tes \\
\hline 6 & 2 & 1 & 2 & 0,33 & Butir tidak mendukung validitas isi tes \\
\hline 7 & 2 & 2 & 2 & 1 & Butir mendukung validitas isi tes \\
\hline 8 & 2 & 2 & 2 & 1 & Butir mendukung validitas isi tes \\
\hline 9 & 2 & 2 & 2 & 1 & Butir mendukung validitas isi tes \\
\hline 10 & 2 & 2 & 2 & 1 & Butir mendukung validitas isi tes \\
\hline 11 & 2 & 1 & 2 & 0,33 & Butir tidak mendukung validitas isi tes \\
\hline 12 & 2 & 2 & 2 & 1 & Butir mendukung validitas isi tes \\
\hline 13 & 2 & 2 & 2 & 1 & Butir mendukung validitas isi tes \\
\hline 14 & 2 & 2 & 2 & 1 & Butir mendukung validitas isi tes \\
\hline 15 & 2 & 2 & 2 & 1 & Butir mendukung validitas isi tes \\
\hline \multicolumn{4}{|c|}{ Jumlah } & 13,32 & Butir mendukung validitas isi tes \\
\hline \multicolumn{4}{|c|}{ Rata-rata } & 0,888 & Butir mendukung validitas isi tes \\
\hline \multicolumn{4}{|c|}{ CVI } & 0,888 & \\
\hline
\end{tabular}

Berdasarkan tabel 1, menunjukkan bahwa terdapat 4 butir soal yang harus direvisi dikarenakan nilai CVR yang dihasilkan CVR minimum. Butir soal tersebut adalah butir soal nomor 1, 2, 6 dan 11. Selanjutnya dilakukan revisi terhadap 4 butir soal tersebut Hasil perhitungan validasi isi menggunakan CVR dapat dilihat pada Tabel 2.

Tabel 2. Hasil Perhitungan Validasi Isi

\begin{tabular}{|c|c|c|c|c|c|c|}
\hline $\begin{array}{c}\text { Butir } \\
\text { Soal }\end{array}$ & $\begin{array}{c}\text { Expert } \\
1 \\
\end{array}$ & $\begin{array}{c}\text { Expert } \\
2 \\
\end{array}$ & $\begin{array}{c}\text { Expert } \\
3 \\
\end{array}$ & CVR & CVI & Keterangan \\
\hline 1 & Ya & Ya & Ya & 1 & \multirow{13}{*}{1} & Butir mendukung validitas isi tes \\
\hline 2 & $\mathrm{Ya}$ & $\mathrm{Ya}$ & $\mathrm{Ya}$ & 1 & & Butir mendukung validitas isi tes \\
\hline 3 & $\mathrm{Ya}$ & $\mathrm{Ya}$ & $\mathrm{Ya}$ & 1 & & Butir mendukung validitas isi tes \\
\hline 4 & $\mathrm{Ya}$ & Ya & Ya & 1 & & Butir mendukung validitas isi tes \\
\hline 5 & $\mathrm{Ya}$ & $\mathrm{Ya}$ & $\mathrm{Ya}$ & 1 & & Butir mendukung validitas isi tes \\
\hline 6 & Ya & Ya & Ya & 1 & & Butir mendukung validitas isi tes \\
\hline 7 & Ya & Ya & Ya & 1 & & Butir mendukung validitas isi tes \\
\hline 8 & $\mathrm{Ya}$ & $\mathrm{Ya}$ & $\mathrm{Ya}$ & 1 & & Butir mendukung validitas isi tes \\
\hline 9 & $\mathrm{Ya}$ & $\mathrm{Ya}$ & $\mathrm{Ya}$ & 1 & & Butir mendukung validitas isi tes \\
\hline 10 & $\mathrm{Ya}$ & Ya & Ya & 1 & & Butir mendukung validitas isi tes \\
\hline 11 & $\mathrm{Ya}$ & Ya & Ya & 1 & & Butir mendukung validitas isi tes \\
\hline 12 & Ya & Ya & Ya & 1 & & Butir mendukung validitas isi tes \\
\hline 13 & $\mathrm{Ya}$ & $\mathrm{Ya}$ & Ya & 1 & & Butir mendukung validitas isi tes \\
\hline
\end{tabular}




\begin{tabular}{|l|c|c|c|c|}
14 & Ya & Ya & Ya & 1 \\
\hline 15 & Ya & Ya & Ya & 2 \\
\hline
\end{tabular}

Berdasarkan tabel 2, menunjukkan bahwa dari 15 butir soal yang ditelah divalidasi telah mendukung validitas isi soal, sehingga soal-soal tersebut dikatakan valid.

\section{Uji Angket Respon Peserta didik}

Tabe1 3. Hasil Analisis Angket Respon Peserta didik

\begin{tabular}{ccc}
\hline Uji Coba & Respon Positif & Respon Negatif \\
\hline One-to-One & $83,3 \%$ & $16,7 \%$ \\
Small Group & $89,5 \%$ & $10,5 \%$ \\
\hline
\end{tabular}

Berdasarkan hasil analisis pada angket respon peserta didik pada instrumen tes kemampuan penalaran matematis pada uji coba one-to-one diperoleh rata-rata respon positif peserta didik adalah $83,3 \%$ dan rata-rata respon negatif peserta didik adalah $16,7 \%$. Sedangkan pada uji coba small group, rata-rata respon positif peserta didik adalah $89,5 \%$ dan rata-rata respon negatif peserta didik adalah 10,5\%. Dapat disimpulkan bahwa lebih dari 50\% peserta didik yang memberikan respon positif. Dengan demikian menurut kriteria pada Bab 3, maka angket respon peserta didik memenuhi kriteria "tercapai" dan tidak ada perbaikan/revisi terhadap instrumen tes yang akan dikembangkan.

\section{Uji Reliabilitas}

Tabel 4. Analisis Reliabilitas Instrumen Tes

\begin{tabular}{|c|c|c|}
\hline \multicolumn{3}{|c|}{ Reliability Statistics } \\
\hline Cronbach's Alpha & $\begin{array}{c}\text { Cronbach's Alpha Based on } \\
\text { Standardized Items }\end{array}$ & $\mathrm{N}$ of Items \\
\hline ,742 & ,732 & 15 \\
\hline
\end{tabular}

Berdasarkan tabel 4 dapat diketahui bahwa tingkat reliabilitas soal tes memiliki interpretasi "Tinggi". Hal ini menunjukkan bahwa instrumen tes dikatakan reliable, sehingga berdasarkan analisis tersebut, maka tidak ada revisi instrumen tes menurut uji reliabilitas.

\section{Uji Tingkat Kesukaran}

Tabel 5. Analisis Tingkat Kesukaran Instrumen Tes

\begin{tabular}{|c|c|c|}
\hline No. Soal & Tingkat Kesukaran & Kategori \\
\hline 1 & 0,61 & Sedang \\
\hline 2 & 0,70 & Sedang \\
\hline 3 & 0,40 & Sedang \\
\hline 4 & 0,49 & Sedang \\
\hline 5 & 0,31 & Sedang \\
\hline
\end{tabular}




\begin{tabular}{|c|c|c|}
\hline 6 & 0,33 & Sedang \\
\hline 7 & 0,27 & Sukar \\
\hline 8 & 0,35 & Sedang \\
\hline 9 & 0,35 & Sedang \\
\hline 10 & 0,32 & Sedang \\
\hline 11 & 0,41 & Sedang \\
\hline 12 & 0,15 & Sukar \\
\hline 13 & 0,10 & Sukar \\
\hline 14 & 0,52 & Sedang \\
\hline 15 & 0,12 & Sukar \\
\hline
\end{tabular}

Berdasarkan tabel 5, diketahui bahwa pada instrumen tes soal nomor 7, 12, 13, dan 15 memiliki tingkat kesukaran "sukar", sedangkan soal nomor 1, 2, 3, 4, 5, 6, 8, 9, 10, 11, dan 14 memiliki tingkat kesukaran "sedang". Sesuai kriteria kualitas instrumen tes pada Bab 3, terdapat butir soal instrumen tes kemampuan penalaran matematis yang dinyatakan memiliki kriteria tingkat kesukaran tidak baik atau terlalu sukar yaitu nomor 7, 12, 13, dan 15.

\section{Daya Pembeda}

Tabel 6. Analisis Daya Pembeda Instrumen Tes

\begin{tabular}{|c|c|c|}
\hline $\begin{array}{c}\text { No. } \\
\text { Soal }\end{array}$ & Daya Beda & Kategori \\
\hline 1 & 0,09 & Sangat Buruk \\
\hline 2 & 0,19 & Buruk \\
\hline 3 & 0,25 & Cungat Baik \\
\hline 4 & 0,50 & Sangat Baik \\
\hline 5 & 0,66 & Sangat Baik \\
\hline 6 & 0,59 & Baik \\
\hline 7 & 0,41 & Sangat Baik \\
\hline 8 & 0,53 & Sangat Baik \\
\hline 9 & 0,63 & Cukup \\
\hline 10 & 0,28 & Cukup Baik \\
\hline 11 & 0,66 & Buruk \\
\hline 12 & 0,25 & Cukup \\
\hline 13 & 0,16 & Sangat Buruk \\
\hline 14 & 0,22 & \\
\hline 15 & 0,09 & \\
\hline
\end{tabular}

Berdasarkan Tabel 6 diketahui bahwa pada instrumen tes, soal nomor 1 dan 15 memiliki daya pembeda dengan kategori "sangat buruk". Soal nomor 2 dan 13 memiliki daya pembeda dengan kategori "buruk". Soal nomor 3, 10, 12, dan 14 memiliki daya pembeda dengan kategori "cukup". Soal nomor 7 memiliki daya pembeda dengan kategori "baik", dan soal nomor 4, 5, 6, 8, 9, dan 11 memiliki daya pembeda de- 
ngan kategori “ sangat baik". Sesuai kriteria kualitas instrumen tes pada bab 3, terdapat butir soal instrumen tes kemampuan penalaran matematis yang dinyatakan memiliki kriteria daya pembeda tidak baik atau tidak dapat membedakan kemampuan bernalar peserta didik antara yang rendah dan tinggi yaitu soal nomor 1, 2, 13, dan 15.

\section{Uji Hasil Kemampuan Penalaran Matematis}

Tabel 7. Analisis Hasil Tes Kemampuan Penalaran Matematis Peserta didik

\begin{tabular}{|r|l|c|c|c|}
\hline No. & $\begin{array}{c}\text { Nilai peserta } \\
\text { didik }\end{array}$ & Frekuensi & Persentase (\%) & Kategori \\
\hline 1 & $80<$ nilai $\leq 100$ & 0 & 0 & Sangat baik \\
\hline 2 & $60<$ nilai $\leq 80$ & 4 & 12,90 & Baik \\
\hline 3 & $40<$ nilai $\leq 60$ & 9 & 29,03 & Cukup \\
\hline 4 & $20<$ nilai $\leq 40$ & 12 & 38,71 & Kurang \\
\hline 5 & $0 \leq$ nilai $\leq 20$ & 6 & 19,35 & Sangat Kurang \\
\hline \multicolumn{2}{|c|}{ Jumlah subyek } & $\mathbf{3 1}$ & $\mathbf{1 0 0 , 0 0}$ & \\
\hline \multicolumn{3}{|c|}{ Rata-rata } & $\mathbf{3 6 , 1 8}$ & Kurang \\
\hline
\end{tabular}

Berdasarkan analisis data instrumen untuk mengukur kemampuan penalaran matematis peserta didik diketahui bahwa dari 31 subjek uji coba lapangan (field test) terdapat 4 peserta didik (12,90 \%) memiliki kemampuan penalaran matematis dengan kategori baik, 9 peserta didik (29,03\%) memiliki kemampuan penalaran matematis dengan kategori cukup, 12 peserta didik $(38,71 \%)$ memiliki kemampuan penalaran matematis dengan kategori kurang, dan 6 peserta didik (19,35\%) memiliki kemampuan penalaran matematis dengan kategori sangat kurang.

\section{SIMPULAN}

Proses pengembangan instrumen tes kemampuan penalaran matematis peserta didik kelas 8 MTs melalui 4 tahapan, yaitu: (a) tahap preliminary, (b) tahap self evaluation, (c) tahap Prototyping, dan (d) tahap field test. Berdasarkan hasil analisis validitas, reliabilitas, instrumen kemampuan penalaran matematis peserta didik yang telah dikembangkan dikategorikan valid dan reliabel. Hal tersebut didapatkan dari hasil analisis CVR dan CVI yang pertama dan kedua berturut-turut 0,978 dan 1 dengan interpretasi sangat sesuai. Hasil analisis reliabilitas sebesar 0,74 dengan interpretasi tinggi. Hasil analisis tingkat kesukaran didapatkan 11 soal dengan interpretasi sedang, dan 4 soal dengan interpretasi sukar. Hasil analisis daya pembeda didapatkan 2 soal dengan interpretasi sangat buruk, 2 soal dengan interpretasi buruk, 4 soal dengan interpretasi cukup, 1 soal dengan interpretasi baik, serta 6 soal dengan interpretasi sangat baik. Serta hasil analisis kemampuan penalaran matematis, tingkat penalaran matematis peserta didik masih rendah.

\section{DAFTAR PUSTAKA}

Al-Tabany, T. I. B. (2015). Mendesain model pembelajaran inovatif, progresif, dan kontekstual. Jakarta: Prenadamedia Group. 
Amri, S. (2013). Pengembangan dan model pembelajaran dalam Kurikulum 2013. Jakarta: Prestasi Pustaka.

Arikunto, S. (2010). Dasar-dasar evaluasi pendidikan (edisi revisi). Jakarta: Bumi Aksara. (2010). Prosedur Penelitian Suatu Pendekatan Praktik.

Bieda, K. N., Ji, X., Drwencke, J., \& Picard, A. (2014). Reasoning-and-proving opportunities in elementary mathematics textbooks. International Journal of Educational Research, 64, 71-80.

Brodie, K. (2010). Teaching mathematical reasoning in secondary school classrooms (Vol. 775). Springer Science \& Business Media.

Emilya, D., Darmawijoyo, D., \& Ilma, R. (2013). Pengembangan Soal-Soal Open-Ended Materi Lingkaran Untuk Meningkatkan Penalaran Matematika Peserta didik Kelas 8 Sekolah Menengah Pertama Negeri 1o Palembang. Jurnal Pendidikan Matematika, 4(2).

English, L. D. (2004). Mathematical and analogical reasoning of young learners. Routledge.

Hamzah, A. (2014). Evaluasi Pembelajaran Matematika. Jakarta: Rajawali Pers.

Hapizah, H. (2014). Pengembangan instrumen kemampuan penalaran matematis Mahapeserta didik pada mata kuliah persamaan diferensial. Kreano, Jurnal Matematika Kreatif-Inovatif, $5(1), 73-81$.

Johnson, H. L. (2012). Reasoning about variation in the intensity of change in covarying quantities involved in rate of change. The Journal of Mathematical Behavior, 31(3), 313-330.

Jurnaidi, J., \& Zulkardi, Z. (2015). Pengembangan Soal Model Pisa Pada Konten Change And Relationship Untuk Mengetahui Kemampuan Penalaran Matematis Peserta didik Sekolah Menengah Pertama. Jurnal Pendidikan Matematika, 8(1), 25-42.

Kusumayanti, A., \& Wutsqa, D. (2016). Keefektifan Model Kolb-Knisley Ditinjau Dari Prestasi Belajar, Kemampuan Penalaran, Dan Self-Esteem Peserta didik. MaPan: Jurnal Matematika Dan Pembelajaran, 4(1), 29-42.

Manfaat, B., Nurhairiyah, S., \& Cirebon, I. S. N. (n.d.). Pengembangan Instrumen Tes Untuk Mengukur Kemampuan Penalaran Statistik Mahapeserta didik Tadris Matematika. Jurnal Beta.

Mustami, M. (2015). Metodologi penelitian pendidikan. Aynat Publishing.

Purwanto, N. (2010). Instrumen Penelitian Sosial dan Pendidikan. Yogyakarta: Pustaka Pelajar.

Sa'adah, W. N. (2010). Peningkatan kemampuan penalaran matematis peserta didik kelas 8 SMP Negeri 3 Banguntapan dalam pembelajaran matematika melalui pendekatan Pendidikan Matematika Realistik Indonesia (PMRI). Skripsi UNY.

Susiana N., S., \& Rosyidi, A. H. (2013). Kemampuan penalaran peserta didik kelas 8 dalam menyelesaikan soal kesebangunan. Jurnal Mahapeserta didik Teknologi Pendidikan, 2(1).

Wassid, I., \& Sunendar, D. (2008). Strategi pembelajaran bahasa. Bandung: Remaja Rosdakarya. 